\title{
Pengaruh Integritas, Kerahasiaan, Kompleksitas Tugas, Motivasi dan Ketidakjelasan Peran Terhadap Kinerja Auditor di Inspektorat Provinsi Jawa Tengah
}

\author{
Marta Hapsari Oktavia \\ Universitas Katolik Soegijapranata \\ martahapsari@gmail.com
}

\begin{abstract}
This study aims to examine the influence of integrity, confidentiality, task complexity, motivation and unclear role on the performance of auditors in the Inspectorate of Central Java Province. The population of this study are all auditors working in Inspectorate of Central Java Province. This research uses primary data and sample selection using convenience sampling method. The sample of 34 auditors from Inspectorate of Central Java Province participate in this study. The results show that integrity has a positive effect on auditor performance. Motivation negatively affects the auditor's performance. While the confidentiality, task complexity and vagueness of the role does not affect the performance of auditors.
\end{abstract}

Keywords: performance, integrity, confidentiality, task complexity, motivation, unclear role

Abstrak

Penelitian ini bertujuan untuk menguji pengaruh integritas, kerahasiaan, kompleksitas tugas, motivasi dan ketidakjelasan peran terhadap kinerja auditor di Inspektorat Provinsi Jawa Tengah. Populasi penelitian ini adalah seluruh auditor yang bekerja di Inspektorat Provinsi Jawa Tengah. Penelitian ini menggunakan data primer dan pemilihan sampel menggunakan metode convenience sampling. Sampel dalam penelitian ini sebesar populasi yaitu 34 auditor yang bekerja di Inspektorat Provinsi Jawa Tengah. Hasil penelitian menunjukan bahwa integritas berpengaruh positif terhadap kinerja auditor. Motivasi berpengaruh negatif terhadap kinerja auditor. Sedangkan kerahasiaan, kompleksitas tugas dan ketidakjelasan peran tidak berpengaruh terhadap kinerja auditor.

Kata kunci: kinerja, integritas, kerahasiaan, kompleksitas tugas, motivasi, ketidakjelasan peran

\section{PENDAHULUAN}

Peran dan fungsi inspektorat Provinsi, Kabupaten/Kota diatur dalam Peraturan Mentri Dalam Negeri No. 64 Tahun 2007 Pasal 4 menyatakan dalam melaksanakan tugas pengawasan urusan pemerintahan, inspektorat mempunyai fungsi: pertama, perencanaan program pengawasan; kedua, perumusan kebijakan dan fasilitas pengawasan; dan ketiga, pemeriksaan, pengusutan, pengujian dan penilaian tugas pengawasan. Peran tersebut digunakan untuk meningkatkan kinerja, transparansi, dan akuntabilitas pengelolaan keuangan negara yang dilakukan melalui pengaturan dan penyelenggaraan sistem pengendalian intern. Dimana untuk mewujudkan akuntabilitas dan meningkatkan kinerja menuju pemerintahan yang bersih, berwibawa dan berdaya saing maka diperlukan dengan adanya pengawasan oleh Aparat Pengawas Intern Pemerintah (APIP). 
Menurut Trisnaningsih (2007), kinerja auditor merupakan tindakan atau pelaksanaan tugas pemeriksaan yang telah diselesaikan oleh auditor dalam kurun waktu tertentu. Kinerja dapat diukur melalui pengukuran tertentu sesuai standar yaitu dimana kualitas yang berkaitan dengan mutu kerja yang dihasilkan, sedangkan kuantitas yang merupakan jumlah dari hasil kerja yang dihasilkan dalam kurun waktu tertentu, dan ketepatan waktu yang merupakan kesesuaian waktu yang telah direncanakan (Andini, 2017).

Berbagai faktor perlu dipertimbangkan untuk meningkatkan kualitas audit internal. Salah satu diantaranya adalah integritas auditor. Integritas auditor dapat menumbuhkan kepercayaan masyarakat terhadap profesi audit karena auditor yang memiliki integritas yang tinggi diharapkan dapat melaksanakan penugasan audit secara profesional. Penelitian Ariani dan Badera (2015) dan Yendrawati dan Narastuti (2014) mendukung hubungan antara integritas dan kinerja auditor.

Faktor lain yang juga dapat mempengaruhi kinerja auditor adalah sikap untuk menjada kerahasiaan bukti audit. Seorang auditor diwajibkan menghargai nilai dan kepemilikan informasi yang diterimanya dan tidak mengungkapkan informasi tersebut tanpa otorisasi yang memadai, kecuali diharuskan oleh peraturan yang berlaku. Dalam hal ini auditor dituntut untuk menjaga semua kerahasiaan informasi pemeriksaan yang diperoleh. Bila kerahasiaan dapat dijaga dengan baik maka dapat mempengaruhi kualitas laporan hasil pemeriksaan yang menjadi penilaian terhadap kinerja auditor (Erina et al. 2012).

Kinerja auditor juga dapat dipengaruhi oleh kompleksitas tugas yang dilakukan auditor. (Khikmah dan Priyanto, 2013). Pemahaman mengenai kompleksitas tugas dapat membatu manajemen audit sehingga memudahkan untuk menemukan solusi terbaik bagi staf audit dan tugas audit. Penelitian Budiasih (2008) menunjukkan bahwa kompleksitas tugas berpengaruh positif terhadap kinerja auditor. Namun, Rustiarini (2013) menemukan kompleksitas tugas berpengaruh negatif terhadap kinerja auditor. Perlu dilakukan penelitian lanjutan sebelum kesimpulan yang definitif dapat diambil.

Seorang auditor pasti memiliki motivasi dari dalam diri, motivasi sendiri juga memiliki peran yang penting dalam menghasilkan kinerja auditor yang baik. Hasil penelitian Widyaningrum (2013) dan Temaja dan Utama (2013) mendukung pengaruh positif motivasi terhadap kinerja auditor.

Ketidakjelasan peran muncul karena kurangnya informasi yang dibutuhkan untuk menyelesaikan tugas-tugas yang diberikan. Kondisi tersebut diungkapkan dalam penelitian Ananta (2013), Ngo (2013) serta Firdausy dan Nazar (2013) yang menunjukkan bahwa ketidakjelasan peran berpengaruh negatif terhadap kinerja auditor. Sehingga semakin tinggi ketidakjelasan peran yang dimiliki auditor maka semakin rendah kinerja auditor.

Penelitian ini bertujuan untuk menguji kembali faktor-faktor yang mempengaruhi kinerja auditor, khususnya kinerja auditor di Inspektorat Provinsi Jawa Tengah. Penelitian ini penting dilakukan karena berbagai temuan menunjukkan bahwa kinerja auditor inspektorat Provinsi Jawa Tengah saat ini menjadi sorotan karena masih ditemukan temuan audit yang tidak berhasil dideteksi oleh aparat inspektorat sebagai auditor internal tetapi terdeteksi oleh Badan Pemeriksa Keuangan (BPK). Temuan BPK menunjukkan adanya kelemahan sistem pengendalian internal dan ketidakpatuhan terhadap ketentuan peraturan perundang-undangan dalam pengelolaan keuangan daerah. Kegagalan tersebut menunjukkan bahwa kualitas auditor internal di lingkungan Inspektorat Provinsi Jawa Tengah masih rendah. 


\section{TINJAUAN LITERATUR DAN PERUMUSAN HIPOTESIS}

\section{Teori Harapan (Expectancy Theory)}

Teori ini menunjukkan kekuatan dari kecenderungan untuk bertindak yang bergantung pada kekuatan suatu harapan bahwa tindakan tersebut akan diikuti hasil yang diinginkan. Teori harapan memperkirakan seorang karyawan akan termotivasi mengeluarkan tingkat usaha yang tinggi ketika karyawan tersebut yakin usaha tersebut menghasilkan penilaian kerja yang baik. Penilaian yang baik akan menimbulkan penghargaan dari organisasi seperti bonus, kenaikan imbalan kerja ataupun promosi. Penghargaan tersebut akan memuaskan tujuan pribadi dari karyawan (Nugroho, et al. 2011). Oleh karena itu, karyawan akan merasa adanya hubungan antara usaha, kinerja, penghargaan serta pemenuhan tujuan pribadi. Motivasi seorang individu akan tinggi bila individu menerima penghargaan atas kinerja tinggi yang dihasilkan sehingga dapat memenuhi kebutuhan mereka.

\section{Kinerja Auditor}

Kinerja adalah hasil dari evaluasi pekerjaan yang dilakukan oleh individu dan dibandingkan dengan kriteria yang telah disepakati bersama, pengertian tersebut menunjukkan bahwa individu melaksanakan tugasnya sesuai dengan tanggung jawab yang diberikan (Irwan, 2016). Kinerja menurut Mulyadi dalam Safitri (2015) adalah akuntan yang melakukan pemeriksaan secara obyektif atas laporan keuangan organisasi untuk menentukan apakah laporan keuangan tersebut telah disajikan secara wajar sesuai dengan prinsip umum akuntansi, untuk semua hal yang material, posisi keuangan dan hasil organisasi tersebut.

Kinerja auditor diukur dengan pengukuran tertentu dimana kualitas berkaitan langsung dengan mutu kerja dan kuantitas berkaitan dengan jumlah hasil dalam kurun waktu tertentu sesuai yang direncanakan (Kasim et al., 2013). Penilaian kinerja merupakan sistem untuk mengetahui apakah karyawan melaksanakan pekerjaan masing-masing secara keseluruhan.

\section{Integritas}

Integritas adalah suatu sikap yang diperlukan oleh seorang auditor karena dengan adanya integritas seorang auditor akan dapat melakukan kinerjanya dengan baik. Sunarto dalam Ariani dan Badera (2015) mengatakan integritas artinya dapat menerima kesalahan yang tidak sengaja dan juga dapat menerima perbedaan pendapat secara jujur, tetapi integritas tidak dapat menerima kecurangan. Seorang auditor harus memiliki kepribadian yang berlandaskan pada kejujuran, keberanian, kebijaksanaan, dan tanggung jawab untuk menjadi dasar dalam pengambilan keputusan. Bila unsur tersebut dapat dipenuhi dan dilaksanakan dengan baik oleh auditor akan dapat menimbulkan kepercayaan dari masyarakat.

Menurut PER/04/M.PAN/03/2008 prinsip integritas memberikan tuntutan kepada auditor untuk : (1) melaksanakan tugasnya secara jujur, teliti, bertanggung jawab dan bersungguh-sungguh; (2) auditor menunjukkan kesetiaan dalam segala hal terkait profesi dan organisasi ketika melaksanakan tugas; (3) auditor mengikuti perkembangan peraturan perundang-undangan dan mengungkapkan segala hal yang ditentukan peraturan perundangundangan dan profesi yang berlaku; (4) auditor menjaga citra dan dapat ikut serta mendukung visi dan misi organisasi; (5) auditor tidak melakukan kegiatan ilegal atau tindakan yang mengdiskreditkan profesi APIP atau organisasi; (6) auditor dapat menggalang kerjasama sehat antar auditor dalam melakukan audit; dan (7) sesama auditor dapat saling mengingatkan, membimbing dan mengoreksi perilaku. 


\section{Kerahasiaan}

Kerahasiaan merupakan sikap yang menutupi atau menyembunyikan sesuatu yang dianggap berharga dan tak seorangpun bisa mengetahuinya dengan mudah. Dalam PER/04/M.PAN/03/2008 bahwa seorang auditor diharuskan menjaga nilai dan kepemilikan informasi, kecuali dalam keadaan mendesak dan diharuskan oleh peraturan yang berlaku. Kerahasiaan juga menjadi salah satu prinsip perilaku yang tercantum dalam kode etik APIP dan harus dimiliki oleh auditor. Dalam PER/04/M.PAN/03/2008 prinsip tersebut menuntut auditor untuk : (1) berhati-hati dalam menggunakan dan menjaga semua informasi yang diperoleh dalam audit; dan (2) auditor tidak menggunakan informasi yang didapat untuk kepentingan pribadi atau golongan di luar kepentingan organisasi dengan cara yang bertentangan dengan peraturan perundang-undangan.

\section{Kompleksitas Tugas}

Tingkat kompleksitas tugas dapat mempengaruhi tahapan audit yang dilakukan auditor. Kompleksitas tugas merupakan persepsi individu mengenai kesulitan suatu tugas yang dikarenakan kapabilitas yang terbatas dan terdiri dari banyak bagian, berbeda-beda dan saling terkait. Seorang akuntan pasti dihadapkan kepada tugas-tugas yang kompleks, banyak, berbeda-beda dan saling terkait sehingga kompleksitas tugas dapat diartikan sebagai fungsi dari tugas itu sendiri. Kompleksitas tugas terdiri dari dua aspek penting. Pertama, kompleksitas mengacu pada informasi yang diproses dan prosedur pekerjaan yang harus dilakukan. Pekerjaan semakin rumit apabila informasi yang akan diproses dan prosedur yang dilakukan semakin banyak. Kedua, kompleksitas koordinatif mengacu pada hubungan antar bagian yang dibutuhkan dalam menyelesaikan suatu pekerjaan. Pekerjaan semakin rumit apabila pekerjaan tersebut berhubungan dengan pekerjaan lainnya.

\section{Motivasi}

Tingkah laku seseorang sangat dipengaruhi oleh motivasi yang mendasari sebelum tindakan tersebut dilakukan. Motivasi merupakan sikap dan juga nilai-nilai yang sangat mempengaruhi individu untuk mencapai tujuannya (Valentina et al., 2017). Motivasi juga dapat diartikan sebagai sumber daya yang dapat mengendalikan perilaku manusia. Menurut Yusuf (2014), terdapat tiga elemen kunci dalam sebuah motivasi yaitu adanya upaya, tujuan organisasi dan kebutuhan. Karyawan yang termotivasi biasanya mengalami ketegangan dan berusaha mengurangi ketegangan tersebut dengan mengelurkan upaya. Sehingga dapat disimpulkan bahwa seseorang yang termotivasi maka akan berupaya untuk mencapai tujuannya, namun belum tentu bila upaya yang dilakukan tinggi akan menghasilkan kinerja yang tinggi. Oleh karena itu, untuk memberikan motivasi perlu mempertimbangkan kualitas dan kuantitas seseorang untuk diarahkan pada pencapaian tujuan.

\section{Ketidakjelasan Peran}

Ketidak jelasan peran memiliki hubungan dengan dua hal : (1) Prediktibilitas atas hasil ataupun respon yang diperoleh terhadap perilaku seseorang; (2) Keberadaan atau kejelasan perilaku yang dibutuhkan dan menyediakan informasi mengenai kesesuaian perilaku tersebut (Firdausy dan Nazar, 2013). Ketika tidak ada informasi mengeai peran, maka ketidakjelasan peran akan terjadi karena orang tidak yakin apa yang seharusnya mereka lakukan (Firdausy dan Nazar, 2013). Secara umum seseorang yang mengalami ketidakjelasan peran pasti merasakan kecemasan, menjadi tidak puas dan juga kurang efektif dalam melakukan tugasnya, sehingga akan menurunkan kinerja mereka. Ketidakjelasan peran akan menghalangi upaya dalam meningkatkan kinerja karyawan karena akan mendorong munculnya keterlambatan dalam mengambil tindakan, kerja karyawan menjadi kurang efisien 
dan tidak terarah, serta akan mendorong munculnya perasaan frustasi dari dalam diri karyawan yang akan mempengaruhi kinerja karyawan itu sendiri (Susanti, 2017).

\section{Pengaruh Integritas terhadap Kinerja Auditor}

Integritas menunjukkan konsistensi sikap dari seseorang terhadap apa yang diucapkan dan yang dilakukan. Menurut Sukriah et al., (2009) integritas memiliki kaitan dengan perilaku individu dalam menerima kesalahan yang tidak disengaja serta perbedaan pendapat yang jujur, tetapi tidak menerima kecurangan terhadap prinsip. Kecurangan prinsip dianggap mengganggu relevansi dari informasi yang dilaporkan dalam laporan keuangan. Sehingga bila di dalam diri auditor tidak terdapat integritas akan memicu perilaku permisif terhadap kode etik auditor yang menyebabkan menurunnya relevansi laporan keuangan, hal tersebut terjadi akibat lemahnya integritas auditor dalam menguji laporan keuangan itu sendiri. Laporan keuangan yang tidak relevan bila digunakan sebagai pembuatan keputusan dapat mengakibatkan terjadinya pengambilan keputusan yang keliru atau bias. Berdasarkan uraian di atas, maka dirumuskan hipotesis penelitian sebagai berikut :

H1 : Integritas berpengaruh positif terhadap kinerja auditor.

\section{Pengaruh Kerahasiaan terhadap Kinerja Auditor}

PER/04/M.PAN/03/2008 mengatakan auditor harus dapat menjaga kerahasiaan informasi yang diperoleh ketika melakukan audit dan hanya dapat memberikan informasi tersebut kepada pihak yang berhak menerimanya sesuai peraturan yang berlaku. Menjaga kerahasiaan tersebut dimaksudkan untuk menjaga keamanan data-data dan juga bukti-bukti yang diperoleh ketika melakukan audit. Dalam upaya menjaga kerahasiaan informasi mengenai objek pemerikasaan, auditor pasti menghadapi tekanan dari pihak lainnya yang mengetahui informasi tersebut. Oleh sebab itu, auditor tidak diperkenankan untuk menggunakan informasi tersebut untuk kepentingan pribadi di luar kepentingan organisasi (Erina et al., 2012). Berdasarkan uraian di atas, maka dirumuskan hipotesis penelitian sebagai berikut :

\section{H2 : Kerahasiaan berpengaruh positif terhadap kinerja auditor.}

\section{Pengaruh Kompleksitas Tugas terhadap Kinerja Auditor}

Kompleksitas tugas didefinisikan sebagai tugas yang tidak terstruktur, sulit dipahami, ambigu dan juga terkait satu sama lain (Surtikanti dan Sunarya, 2012). Pengertian tersebut menjelaskan mengenai persepsi seseorang terhadap suatu tugas yang dikerjakan. Menurut Agusniwar et al., (2017), kompleksitas tugas merupakan persepsi individu mengenai suatu tugas yang dianggap sulit karena terbatasnya kapabilitas dari bagian-bagian yang banyak, berbeda dan saling terkait. Persepsi tersebut menimbulkan kemungkinan suatu tugas dianggap sulit bagi seseorang, namun mungkin mudah bagi orang lain. Seorang akuntan pasti akan dihadapkan dengan tugas yang kompleks, banyak dan saling terkait. Beberapa tugas audit dianggap sebagai tugas yang memiliki kompleksitas tinggi dan sulit sedangkan yang lainnya beranggapan sebagai tugas yang mudah (Engko, 2007).

Berdasarkan penelitian yang dilakukan Budiasih (2008), Khikmah dan Priyanto (2013) menunjukkan bahwa kompleksitas tugas memiliki pengaruh positif terhadap kinerja seorang auditor serta penelitian yang dilakukan oleh Rustiarini (2013) yang menunjukkan bahwa kompleksitas tugas memiliki pengaruh negatif terhadap kinerja seorang auditor. Berdasarkan uraian di atas, maka dirumuskan hipotesis penelitian sebagai berikut :

H3 : Kompleksitas tugas berpengaruh terhadap kinerja auditor. 


\section{Pengaruh Motivasi terhadap Kinerja Auditor}

Motivasi adalah dorongan yang muncul dalam diri seseorang secara sadar maupun tidak sadar untuk melakukan tindakan dengan tujuan tertentu (Afriyani et al., 2014). Menurut Triyanthi dan Budiartha (2015), Standar Profesional Akuntan Publik menyatakan dalam upaya memenuhi persyaratan sebagai seorang yang profesional, auditor harus memiliki motivasi kerja. Motivasi kerja merupakan pemberian daya gerak yang menciptakan kegairahan pada diri seseorang agar mereka mau bekerja sama, bekerja efektif dan terintegrasi dengan segala upayanya untuk mencapai kinerja yang maksimal (Darmawan et al., 2011). Menurut Temaja dan Utama (2016), motivasi kerja dari seorang auditor akan membantu untuk mendukung semangat dan juga kecepatan auditor dalam menyelesaikan tugasnya sehingga tingkat kesalahan akan semakin berkurang. Berdasarkan uraian di atas, maka dirumuskan hipotesis penelitian sebagai berikut :

\section{H4 : Motivasi berpengaruh positif terhadap kinerja auditor.}

\section{Pengaruh Ketidakjelasan peran terhadap Kinerja Auditor}

Ketidakjelasan peran dapat membuat seseorang mengalami kecemasan, ketidakpuasan, serta kurang efektif dalam melaksanakan tugas sehingga menyebabkan kinerja menurun (Sari dan Suryanawa, 2016). Ketidakjelasan peran dapat timbul akibat kurangnya informasi mengenai tugas dan tanggung jawab yang harus dilakukan oleh seorang auditor. Hal tersebut membuat auditor mengalami kebingungan sehingga tidak dapat maksimal dalam melaksanakan tugas dan tanggung jawabnya. Pada umumnya seorang auditor yang mengalami ketidakjelasan peran akan merasa cemas, menjadi lebih tidak puas dan tidak melakukan tugas dengan efektif sehingga dapat menurunkan kinerja mereka.

Pernyataan tersebut didukung oleh penelitian Ananta (2013), Ngo (2013) serta penelitian Firdausy dan Nazar (2013) yang menunjukkan bahwa ketidakjelasan peran berpengaruh negatif terhadap kinerja seorang auditor. Berdasarkan uraian di atas, maka dirumuskan hipotesis penelitian sebagai berikut :

H5 : Ketidakjelasan peran berpengaruh negatif terhadap kinerja auditor.

\section{METODA PENELITIAN}

\section{Populasi dan Sampel Penelitian}

Populasi yang digunakan adalah seluruh auditor internal yang bekerja di Inspektorat Provinsi Jawa Tengah. Peneliti memilih sampel menggunakan metode sensus yaitu pembagian atau penyebaran kuesioner yang dilakukan pada semua populasi sehingga jumlah kuesioner yang akan disebar atau dibagikan kepada responden adalah sebanyak jumlah populasi yaitu 34 kuesioner.

Jenis data dalam penelitian ini adalah data primer berupa data hasil jawab dari kuesioner yang dibagikan kepada auditor yang bekerja di Inspektorat Provinsi Jawa Tengah sebagai responden dalam penelitian ini. Sumber penelitian ini berasal dari skor masingmasing indikator variabel yang diperoleh dari pengisian kuesioner yang telah dibagikan kepada responden.

\section{Definisi Operasional dan Pengukuran Variabel}

\section{Kinerja Auditor (Y)}

Menurut Revita (2015) kinerja auditor merupakan hasil kerja secara kualitas dan kuantitas yang dicapai oleh seorang pegawai dalam melaksanakan tugasnya sesuai dengan tanggungjawab yang diberikan kepadanya. Kinerja auditor diukur dengan menggunakan 14 item pernyataan yang menggambarkan tingkat persepsi auditor terhadap proses audit. 
Instrumen yang digunakan untuk mengukur kinerja auditor ini diadopsi dari penelitian Arini (2010). Indikator yang digunakan sebagai berikut :

1) Kualitas pekerjaan.

a. Ketepatan waktu :

- Penyusunan rencana dan program audit

- Pelaksanaan audit

b. Kesesuaian pemeriksaan dengan standar audit APIP

2) Kuantitas pekerjaan / jumlah output.

\section{Integritas $\left(\mathbf{x}_{1}\right)$}

Integritas adalah sikap yang jujur, berani, bijaksana serta bertanggungjawab yang harus dimiliki oleh auditor dalam melaksanakan tugas audit (Sukriah et el., 2009). Integritas diukur dengan menggunakan 14 item pernyataan yang menggambarkan tingkat persepsi auditor terhadap kode etik auditor. Instrumen yang digunakan untuk mengukur integritas ini diadopsi dari penelitian Arini (2010). Indikator yang digunakan sebagai berikut :

1) Kejujuran auditor.

2) Keberanian auditor.

3) Sikap bijaksana auditor.

4) Tanggungjawab auditor.

\section{Kerahasiaan $\left(\mathbf{X}_{2}\right)$}

Kerahasiaan adalah sikap auditor dalam menghargai nilai dan juga kepemilikan informasi yang diterimanya serta tidak mengungkapkan informasi tersebut tanpa otorisasi yang memadai, kecuali diharuskan oleh peraturan perundang-undangan (PER/04/M.PAN/03/2008). Kerahasiaan diukur dengan menggunakan 5 item pernyataan yang menggambarkan tingkat persepsi auditor terhadap kode etik auditor. Instrumen yang digunakan untuk mengukur kerahasiaan diadopsi dari penelitian Arini (2010). Indikator yang digunakan sebagai berikut :

1) Kehati-hatian atas informasi yang diperoleh.

2) Penggunaan dan pengungkapan informasi.

\section{Kompleksitas Tugas $\left(\mathbf{X}_{3}\right)$}

Kompleksitas tugas adalah persepsi individu terhadap tugas yang tidak terstruktur, sulit dipahami, dan ambigu (Parhan, 2018). Kompleksitas tugas diukur dengan menggunakan 6 item pernyataan yang menggambarkan tingkat persepsi auditor terhadap tugas yang dikerjakan. Instrumen yang digunakan untuk mengukur kompleksitas tugas.

\section{Motivasi $\left(\mathbf{X}_{4}\right)$}

Menurut Rivai (2009) dalam Valentina et al., (2017), motivasi adalah serangkaian sikap dan nilai-nilai yang mempengaruhi individu untuk mencapai hal yang spesifik sesuai dengan tujuan individu. Motivasi diukur dengan menggunakan 7 item pernyataan yang menggambarkan tingkat persepsi auditor terhadap diri auditor dalam memberikan kinerja yang terbaik. Instrumen yang digunakan untuk mengukur motivasi diadopsi dari penelitian Siregar (2012). 


\section{Ketidakjelasan Peran $\left(\mathrm{X}_{5}\right)$}

Ketidakjelasan peran adalah kurangnya informasi yang dimiliki serta tidak adanya arah dan kebijakan yang jelas, ketidakpastian tentang otoritas, kewajiban dan hubungan lainnya, dan ketidakpastian sanksi terhadap perilaku yang dilakukan (Azhar, 2013). Ketidakjelasan peran diukur dengan menggunakan 5 item pernyataan yang menggambarkan tingkat persepsi auditor terhadap tugas dilakukan. Instrumen yang digunakan untuk mengukur ketidakjelasan peran diadopsi dari penelitian Agustina (2009).

\section{Komitmen Organisasional}

Komitmen karyawan pada organisasi adalah perasaan suka atau tidak suka seorang karyawan terhadap organisasi tempat dia bekerja (Wildan, 2016). Komitmen organisasional diukur dengan menggunakan 7 item pernyataan yang menggambarkan tingkat persepsi auditor terhadap organisasinya. Instrumen yang digunakan untuk mengukur komitmen organisasional diadopsi dari penelitian Siregar (2012).

\section{Kompetensi}

Kompetensi adalah kualifikasi yang dibutuhkan auditor dalam melaksanakan audit denga benar, yang diukur dengan indikator mutu personal, pengetahuan umum dan keahlian khusus (Sukriah et al., 2009). Auditor yang memiliki kompetensi yang baik maka pemahamannya atas laporan keuangan juga akan lebih baik sehingga auditor dapat dengan cepat ketika melakukan analisis mengenai kesalahan yang terjadi (Ariani dan Badera, 2015). Kompetensi diukur dengan menggunakan 10 item pernyataan yang menggambarkan tingkat persepsi auditor terhadap pengetahuan dan keahlian yang dimiliki. Instrumen yang digunakan untuk mengukur kompetensi diadopsi dari penelitian Arini (2010). Indikator yang digunakan sebagai berikut :

1) Mutu personal.

2) Pengetahuan umum.

3) Keahlian khusus.

\section{Model Analisis}

Pengujian hipotesis dilakukan dengan menggunakan model analisis regresi berganda untuk memprediksi berapa besar kekuatan pengaruh variabel independen terhadap variabel dependen. Persamaan regresinya adalah :

$$
\begin{gathered}
\text { Kinerja }=\alpha+\beta_{1} \text { integritas }+\beta_{2} \text { Rahasia }+\beta_{3} \text { Kompleks }+\beta_{4} \text { Motivasi }+ \\
\beta_{5} \text { Ketidakjelasan }+\beta_{6} \text { Komitmen }+\beta_{7} \text { Kompetensi } \\
+\mathrm{e}
\end{gathered}
$$

\section{HASIL DAN PEMBAHASAN}

\section{Deskripsi Responden}

Bagian ini memaparkan hasil penelitian berupa kuesioner yang telah dibagikan ke Inspektorat Provinsi Jawa Tengah. Kuesioner telah disebarkan kepada 34 responden dan kuesioner yang kembali sebanyak 34 buah. Sehingga untuk tingkat pengembalian kuesioner sebesar $100 \%$. Gambaran mengenai responden dilakukan dengan melakukan pengelompokan berdasarkan umur, jenis kelamin, tingkat pendidikan, jabatan dan masa kerja. Deskripsi mengenai karakteristik responden dapat dilihat pada tabel berikut : 
Tabel 4.1

Usia Responden

\begin{tabular}{|l|l|r|r|l|r|}
\hline & N & \multicolumn{1}{|c|}{ Minimum } & Maximum & Mean & Std. Deviation \\
\hline Umur & 34 & 37,00 & 59,00 & 49,352 & 7,44223 \\
& & & & 9 & \\
\hline
\end{tabular}

Sumber : Data primer yang diolah, 2018

Berdasarkan tabel 4.1 dapat diketahui bahwa responden dalam penelitian ini memiliki usia paling rendah 37 tahun dan paling tinggi berusia 59 tahun. Rata-rata usia responden yang berpartisipasi adalah 49 tahun.

Tabel 4.2

Jenis Kelamin Responden

\begin{tabular}{|l|r|r|r|r|}
\hline & & & Valid & Cumulative \\
& Frequency & Percent & Percent & Percent \\
\hline laki-laki & 22 & 64,7 & 64,7 & 64,7 \\
perempuan & 12 & 35,3 & 35,3 & 100,0 \\
Total & 34 & 100,0 & 100,0 & \\
\hline
\end{tabular}

Sumber : Data primer yang diolah, 2018

Berdasarkan tabel 4.2 dapat diketahui bahwa responden yang berjenis kelamin laki-laki sebanyak 22 orang $(64,7 \%)$ dan perempuan sebanyak 12 orang $(35,3 \%)$. Sehingga dapat disimpulkan bahwa mayoritas responden berjenis kelamin laki-laki.

Tabel 4.3

Tingkat Pendidikan Responden

\begin{tabular}{|rl|r|r|r|r|}
\hline & & Frequency & Percent & Valid Percent & Cumulative Percent \\
\hline Valid & S1 & 15 & 44,1 & 44,1 & 44,1 \\
& S2 & 19 & 55,9 & 55,9 & 100,0 \\
& Total & 34 & 100,0 & 100,0 & \\
\hline
\end{tabular}

Sumber : Data primer yang diolah, 2018

Berdasarkan tabel 4.3 dapat diketahui bahwa responden yang tingkat pendidikannya S1 sebanyak 15 orang $(44,1 \%)$ dan S2 sebanyak 19 orang $(55,9 \%)$.

Tabel 4.4

Jabatan Responden

\begin{tabular}{|l|r|r|r|r|}
\hline & Frequency & Percent & \multicolumn{1}{|c|}{$\begin{array}{c}\text { Valid } \\
\text { Percent }\end{array}$} & $\begin{array}{c}\text { Cumulative } \\
\text { Percent }\end{array}$ \\
\hline Auditor & 3 & 8,8 & 8,8 & 8,8 \\
Pertama & 18 & 52,9 & 52,9 & 61,8 \\
Auditor Muda & 13 & 38,2 & 38,2 & 100,0 \\
Auditor & 34 & 100,0 & 100,0 & \\
Madya & & \\
Total & & \\
\hline
\end{tabular}

Sumber : Data primer yang diolah, 2018

Berdasarkan tabel 4.4 dapat diketahui bahwa responden yang memiliki jabatan auditor pertama sebanyak 3 orang $(8,8 \%)$, auditor muda sebanyak 18 orang $(52,9 \%)$ dan auditor madya sebanyak 13 orang $(38,2 \%)$. 
Tabel 4.5

Masa Kerja Responden

\begin{tabular}{|l|r|r|r|r|r|}
\hline & $\mathrm{N}$ & Minimum & Maximum & Mean & Std. Deviation \\
\hline Masa_Kerja & 34 & 5,00 & 35,00 & 19,088 & 2 \\
& & & & 8,45440 \\
\hline
\end{tabular}

Sumber : Data primer yang diolah, 2018

Tabel 4.5 menunjukkan bahwa dari 34 responden yang berpartisipasi dalam penelitian ini memiliki masa kerja minimal 5 tahun dan maksimal 35 tahun dengan rata - rata lama bekerja responden adalah 19 tahun.

\section{Validitas dan Reliabilitas}

Uji validitas ini dilakukan dengan membandingkan nilai $r$ hitung dengan nilai $r$ tabel pada output SPSS. Pertanyaan tersebut dikatakan valid jika nilai $r$ hitung $>r$ tabel. Dalam penelitian ini taraf signifikansi yang digunakan adalah 5\% dan jumlah sampel (n) 34 dengan $\mathrm{df}=32$ sehingga nilai $\mathrm{r}$ tabel yang digunakan adalah 0,287 (two tailed). Dari hasil pengujian menunjukkan bahwa bahwa semua item pertanyaan dinyatakan valid.

Reliabilitas merupakan alat untuk mengukur suatu kuesioner yang merupakan indikator dari variabel. Kuesioner dikatakan handal jika jawaban dari responden terhadap pertanyaan adalah konsisten. Uji reliabilitas ini menggunakan uji statistik Cronbach Alpha $(\alpha)$, semakin tinggi nilai Cronbach Alpha maka tingkat reliabilitas data semakin baik. Tabel 4.6 menyajikan hasil pengujian reliabilitas. Dari hasil pengujian reliabilitas diatas dapat diketahui bahwa nilai Cronbach Alpha tidak ada yang digolongkan pada kriteria reliabilitas rendah yang artinya instrumen yang digunakan semakin handal karena nilai Cronbach Alpha yang tinggi. Sehingga dapat dikatakan bahwa seluruh variabel dalam penelitian ini reliabel.

\section{Tabel 4.6}

Hasil Pengujian Reliabilitas

\begin{tabular}{|l|c|l|}
\hline \multicolumn{1}{|c|}{ Variabel } & Cronbach's Alpha & \multicolumn{1}{c|}{ Keterangan } \\
\hline Integritas & 0,928 & Reliabilitas Sempurna \\
\hline Kerahasiaan & 0,907 & Reliabilitas Sempurna \\
\hline Kompleksitas Tugas & 0,597 & Reliabilitas Moderat \\
\hline Motivasi & 0,822 & Reliabilitas Tinggi \\
\hline Ketidakjelasan Peran & 0,955 & Reliabilitas Sempurna \\
\hline Komitmen Organisasional & 0,864 & Reliabilitas Tinggi \\
\hline Kompetensi & 0,883 & Reliabilitas Tinggi \\
\hline Kinerja Auditor & 0,907 & Raliabilitas Sempurna \\
\hline
\end{tabular}

Sumber : Data primer yang diolah

\section{Statistik Deskriptif}

Tabel 4.7 menyajikan statistik deskriptif dari seluruh variabel yang digunakan dalam penelitian. Dari tabel dapat diketahui bahwa rata-rata jawaban responden yang berpartisipasi dalam penelitian ini untuk variabel integritas sebesar 63,70 dan termasuk dalam kategori tinggi. Hal ini berarti integritas responden dikatakan sangat baik karena integritas merupakan dasar utama kepercayaan masyarakat terhadap suatu profesi. 
Rata-rata jawaban responden yang berpartisipasi dalam penelitian ini untuk variabel kerahasiaan sebesar 22,88 dan termasuk dalam kategori tinggi. Hal ini berarti kerahasiaan dikatakan sangat baik karena kerahasiaan ini mewajibkan auditor untuk menghargai nilai dan kepemilikan informasi yang diperoleh sesuai peraturan perundang-undangan yang berlaku.

Tabel 4.7

Statistik Deskriptif

\begin{tabular}{|c|c|c|c|c|c|c|c|}
\hline \multirow{2}{*}{ Variabel } & \multirow{2}{*}{$\begin{array}{l}\text { Kisaran } \\
\text { Teoritis }\end{array}$} & \multirow{2}{*}{$\begin{array}{c}\text { Kisaran } \\
\text { Aktual }\end{array}$} & \multirow{2}{*}{$\begin{array}{c}\text { Rata- } \\
\text { Rata } \\
\text { (mean) }\end{array}$} & \multicolumn{3}{|c|}{ Range Kategori Jawaban } & \multirow{2}{*}{ Keterangan } \\
\hline & & & & Rendah & Sedang & Tinggi & \\
\hline Integritas & $14-70$ & $55-70$ & 63,70 & $14-32,7$ & $32,8-51,4$ & $51,5-70$ & Tinggi \\
\hline Kerahasiaan & $5-25$ & $20-25$ & 22,88 & $5-11,7$ & $11,8-18,4$ & $18,5-25$ & Tinggi \\
\hline Kompleksitas Tugas & $6-30$ & $9-18$ & 13,44 & $6-14$ & $14,1-22$ & $22,1-30$ & Rendah \\
\hline Motivasi & $7-35$ & $21-35$ & 29,91 & $7-16,3$ & $16,4-25,6$ & $25,7-35$ & Tinggi \\
\hline Ketidakjelasan Peran & $5-25$ & $5-15$ & 9,94 & $5-11,7$ & $11,8-18,4$ & $18,5-25$ & Rendah \\
\hline Komitmen Organisasional & $7-35$ & $22-35$ & 29,79 & $7-16,3$ & $16,4-25,6$ & $25,7-35$ & Tinggi \\
\hline Kompetensi & $10-50$ & $37-50$ & 44,15 & $10-23,3$ & $23,4-36,6$ & $36,7-50$ & Tinggi \\
\hline Kinerja Auditor & $14-70$ & $44-70$ & 58,53 & $14-32,7$ & $32,8-51,4$ & $51,5-70$ & Tinggi \\
\hline
\end{tabular}

Sumber : Data primer yang diolah

Rata-rata jawaban responden yang berpartisipasi dalam penelitian ini untuk variabel kompleksitas tugas sebesar 13,44 dan termasuk dalam kategori rendah. Hal ini berarti kompleksitas tugas dikatakan kurang baik karena kompleksitas tugas ini merupakan pemahaman individu terhadap suatu tugas dimana tugas dianggap sulit untuk dipahami, rendahnya kompleksitas tugas berarti individu beranggapan bahwa mereka tidak merasa menghadapi tugas yang kompleks atau dapat dikatakan semua tugas yang dihadapi mudah untuk dipahami.

Rata-rata jawaban responden yang berpartisipasi dalam penelitian ini untuk variabel motivasi sebesar 29,91 dan termasuk dalam kategori tinggi. Hal ini berarti motivasi dikatakan sangat baik karena motivasi memberikan dorongan gairah kerja dengan memberikan semua kemampuan dan keterampilan.

Rata-rata jawaban responden yang berpartisipasi dalam penelitian ini untuk variabel ketidakjelasan peran sebesar 9,94 dan termasuk dalam kategori rendah. Hal ini berarti ketidakjelasan dikatakan cukup rendah karena ketidakjelasan peran ini merupakan kurangnya informasi mengenai tugas yang akan dikerjakan, ketidakjelasan yang rendah menyatakan bahwa responden merasa bahwa informasi mengenai tugas yang akan dikerjakan sudah jelas sehingga tidak terjadi ketimpangan.

Rata-rata jawaban responden yang berpartisipasi dalam penelitian ini untuk variabel komitmen organisasional sebesar 29,79 dan termasuk dalam kategori tinggi. Hal ini berarti responden dikatakan sangat baik karena memiliki keinginan yang tinggi untuk menjaga atau memelihara keanggotaannya dalam organisasi.

Rata-rata jawaban responden yang berpartisipasi dalam penelitian ini untuk variabel kompetensi sebesar 44,15 dan termasuk dalam kategori tinggi. Hal ini berarti kompetensi dikatakan sangat baik karena responden memiliki kemampuan serta pengetahuan yang diperoleh dari pendidikan dan pengalamannya dalam melakukan suatu pekerjaan. 
Rata-rata jawaban responden yang berpartisipasi dalam penelitian ini utnuk variabel kinerja auditor sebesar 58,53 dan termasuk dalam kategori tinggi. Hal ini berarti kinerja auditor dikatakan sangat baik karena persepsi responden atas hasil kerja terhadap kontribusinya dalam suatu organisasi.

\section{Uji Normalitas}

Uji normalitas bertujuan untuk menguji apakah model regresi, variabel residual memiliki distribusi normal. Untuk uji normalitas data dalam penelitian ini menggunakan uji nonparametrik yaitu uji Kolmogorov-Smirnov Test, distribusi data dikatakan normal jika nilai probabilitas (sig) Kolmogorov-Smirnov $>\alpha=0,05$.

Tabel 4.8

Hasil Uji Normalitas

\begin{tabular}{|ll|r|}
\hline & & \multicolumn{1}{|c|}{ Standardized Residual } \\
\hline Normal Parameters ${ }^{\mathrm{a}, \mathrm{b}}$ & & 34 \\
& Mean &, 0000000 \\
Most Extreme Differences & Std. Deviation &, 88762536 \\
& Absolute &, 146 \\
& Positive &, 126 \\
& Negative &,- 146 \\
Test Statistic & &, 146 \\
Asymp. Sig. (2-tailed) & &, $063^{\mathrm{c}}$ \\
\hline
\end{tabular}

Sumber : Data primer yang diolah, 2018

Berdasarkan tabel 4.8 nilai Kolmogrov-Smirnov yaitu pada Test statistic sebesar 0,146 dengan signifikansi 0,063 . Nilai signifikansi $>\alpha=0,05$ berarti bahwa data residual terdistribusi normal.

\section{Uji Heteroskedastisitas}

Uji Heteroskedastisitas digunakan untuk menguji apakah dalam model regresi terjadi ketidaksamaan variance dari residual suatu pengamatan ke pengamatan yang lain. Dilakukan dengan uji Glejser, jika nilai absolut lebih besar dari alpha $(\alpha)$ maka tidak terdapat heteroskedastisitas. Berdasarkan hasil pengujian heterokedastisitas pada tabel 4.9 dapat dilihat bahwa variabel integritas, kerahasiaan, kompleksitas tugas, motivasi, ketidakjelasan peran, komitmen organisasional dan kompetensi memberikan masing-masing nilai sig. > 0,05. Sehingga dapat disimpulkan seluruh variabel telah terbebas dari masalah heteroskedastisitas.

Tabel 4.9

Hasil Uji Heteroskedastisitas

\begin{tabular}{|c|c|c|c|c|c|c|}
\hline \multirow{2}{*}{\multicolumn{2}{|c|}{ Model }} & \multicolumn{2}{|c|}{$\begin{array}{c}\text { Unstandardized } \\
\text { Coefficients }\end{array}$} & \multirow{2}{*}{$\begin{array}{l}\text { Standardized } \\
\text { Coefficients } \\
\text { Beta }\end{array}$} & \multirow[b]{2}{*}{$\mathrm{T}$} & \multirow[b]{2}{*}{ Sig. } \\
\hline & & $\mathrm{B}$ & Std. Error & & & \\
\hline \multirow[t]{8}{*}{1} & (Constant) & 2,303 & 8,452 & & ,272 & ,787 \\
\hline & Integritas & , 143 & , 128 & ,353 & 1,115 & ,275 \\
\hline & Rahasia &,- 076 & ,232 &,- 072 &,- 329 & ,745 \\
\hline & Kompleks &,- 128 & ,214 &,- 135 &,- 595 & ,557 \\
\hline & Motivasi & ,020 &, 164 & ,029 &, 121 & ,905 \\
\hline & Ketidakjelasan & ,086 & , 193 & ,096 & ,446 & ,659 \\
\hline & Komitmen &,- 063 &, 146 &,- 102 &,- 431 & ,670 \\
\hline & Kompetensi &,- 115 &, 153 &,- 229 &,- 750 & , 460 \\
\hline
\end{tabular}

Sumber : Data primer yang diolah, 2018 


\section{Uji Multikolinearitas}

Uji multikolenearitas digunakan untuk menguji apakah model regresi ditemukan adanya korelasi antar variabel independen. Hasilnya dapat dilihat pada tabel 4.10. Cara mendeteksi multikolinearitas yaitu melalui tolerance value dan VIF (Variance Inflation Factor). Jika tolerance value $<1$ dan VIF $<10$ maka tidak terjadi multikolinearitas.

Tabel 4.10

Hasil Uji Multikolinearitas

\begin{tabular}{|c|c|c|c|c|}
\hline \multirow[b]{2}{*}{ Model } & \multicolumn{2}{|c|}{$\begin{array}{l}\text { Unstandardized } \\
\text { Coefficients }\end{array}$} & \multicolumn{2}{|c|}{$\begin{array}{c}\text { Collinearity } \\
\text { Statistics }\end{array}$} \\
\hline & B & $\begin{array}{l}\text { Std. } \\
\text { Error }\end{array}$ & Tolerance & VIF \\
\hline 1 (Constant) & 15,199 & 13,069 & & \\
\hline Integritas & ,505 & , 198 & ,357 & 2,803 \\
\hline Rahasia & ,411 & ,359 & ,742 & 1,347 \\
\hline Kompleks & ,277 & ,332 & ,696 & 1,436 \\
\hline Motivasi &,- 745 &, 254 & ,607 & 1,648 \\
\hline Ketidakjelasan &,- 352 & ,298 & ,778 & 1,285 \\
\hline Komitmen &,- 148 & ,226 & ,646 & 1,547 \\
\hline Kompetensi & ,640 & ,237 & ,384 & 2,603 \\
\hline
\end{tabular}

Variabel integritas, rahasia, kompleks, motivasi, ketidakjelasan, komitmen, dan kompetensi memberikan masing-masing nilai tolerance kurang dari 1 dan nilai VIF lebih kecil dari 10 sehingga dapat disimpulkan bahwa pada penelitian ini tidak ada indikasi multikolinearitas.

\section{Pengujian Hipotesis}

Hasil pengujian hipotesis dapat dilihat pada tabel 4.11. Dari tabel dapat disimpulkan bahwa variabel integritas dan kompetensi diterima. Sedangkan variabel independen lainnya tidak terdukung secara statistik.

Tabel 4.11

Hasil Regresi Linear

\begin{tabular}{|l|r|r|r|r|r|c|}
\hline \multirow{2}{*}{ Model } & \multicolumn{2}{|c|}{$\begin{array}{c}\text { Unstandardized } \\
\text { Coefficients }\end{array}$} & & & & \\
\cline { 2 - 4 } & \multicolumn{1}{|c|}{$\mathrm{B}$} & \multicolumn{1}{|c|}{$\begin{array}{c}\text { Std. } \\
\text { Error }\end{array}$} & \multicolumn{1}{c|}{$\mathrm{T}$} & Sig. & Sig./ 2 & Hasil \\
\hline Integritas & 15,199 & 13,069 & 1,163 &, 255 & 0,127 & \\
Rahasia &, 505 &, 198 & 2,550 &, 017 & 0,008 & Diterima \\
Kompleks &, 411 &, 359 & 1,144 &, 263 & 0,131 & Ditolak \\
Motivasi &, 277 &, 332 &, 834 &, 412 & 0,206 & Ditolak \\
Ketidakjelasan &,- 745 &, 254 & $-2,936$ &, 007 & 0,003 & Ditolak \\
Komitmen &,- 352 &, 298 & $-1,181$ &, 248 & 0,124 & Ditolak \\
Kompetensi &,- 148 &, 226 &,- 657 &, 517 & 0,258 & Ditolak \\
\end{tabular}




\section{PEMBAHASAN}

\section{Pengaruh integritas terhadap kinerja auditor.}

Berdasarkan hasil pengujian statistik pada tabel 4.11, hipotesis pertama yaitu integritas berpengaruh positif terhadap kinerja auditor diterima karena hasil dari sig/2 menunjukan nilai 0,008 dengan koefisien beta positif sebesar 0,505 maka hipotesis penulis diterima. Hal tersebut sesuai dengan hasil penelitian Ariani dan Badera (2015), Yendrawati dan Narastuti (2014) serta penelitian Baisary (2013) bahwa integritas memiliki peran terhadap kinerja auditor.

Dalam penelitian Ariani dan Badera sikap integritas artinya dapat menerima kesalahan yang tidak sengaja dan juga dapat menerima perbedaan pendapat secara jujur, tetapi integritas tidak dapat menerima kecurangan. Sehingga intergitas dapat dikatakan sebagai sikap jujur, transparansi, berani, bijaksana, dan bertanggung jawab yang dibangun auditor yang akan menghasilkan kinerja yang baik. Sikap tersebut merupakan karakteristik dari intergritas seperti yang diungkapkan dalam kode etik APIP.

\section{Pengaruh kerahasiaa terhadap kinerja auditor.}

Berdasarkan hasil pengujian statistik, hipotesis kedua yaitu kerahasiaan berpengaruh positif terhadap kinerja auditor ditolak karena hasil dari sig/2 menunjukan nilai 0,131>0,05 dengan koefisien beta positif sebesar 0,411 maka hipotesis penulis ditolak. Hal tersebut juga diungkapkan oleh penelitian Arini (2010) yang menyatakan bahwa kerahasiaan tidak memiliki pengaruh terhadap kinerja.

Berdasarkan hasil pengujian statistik deskriptif kerahasiaan auditor memiliki rata-rata 22,88 yang termasuk kategori tinggi sehingga dapat dikatakan sangat baik. Namun, berdasarkan penelitian yang dilakukan menunjukkan bahwa bisa jadi auditor mampu menjaga kerahasiaan tetapi karena kurangnya pengawasan maka kinerja auditor menjadi tidak maksimal. Kurangnya pengawasan memungkinkan auditor menggunakan informasi yang diperoleh untuk kepentingan di luar organisasi. Apabila auditor menggunakan informasi yang diperoleh untuk kepentingan di luar organisasi maka auditor tidak akan memperoleh kepercayaan publik dan mencerminkan auditor yang tidak bersikap profesional. Hal tersebut menunjukkan bahwa auditor tidak dapat diandalkan dan tidak dipercaya sehingga kinerjanya diragukan.

\section{Pengaruh kompleksitas tugas terhadap kinerja auditor.}

Berdasarkan hasil pengujian statistik, hipotesis ketiga yaitu kompleksitas tugas berpengaruh terhadap kinerja auditor ditolak karena hasil dari sig/2 menunjukan nilai 0,206 > 0,05dengan koefisien beta negatif sebesar 0,277 maka hipotesis penulis ditolak. Hasil penelitian serupa juga dilakukan oleh Rustiarini (2013) yang mengungkapkan bahwa kompleksitas tugas tidak berpengaruh terhadap kinerja.

Hal tersebut menunjukkan bahwa adanya tugas yang kompleks pada pekerjaan audit tidak akan memberikan pengaruh terhadap kinerja auditor karena auditor menganggap bahwa tugas-tugas yang kompleks merupakan suatu hal yang pasti dijumpai dalam proses audit, selain itu auditor juga tidak mengalami kesulitan dalam memahami tugas yang akan dilakukannya sehingga dapat melakukan tugasnya dengan baik. Hasil dari penelitian ini didukung dengan adanya data statistik deskriptif yang menyatakan bahwa variabel kompleksitas tugas memiliki rata-rata sebesar 13,44 yang dikategorikan rendah sehingga dapat dikatakan bahwa kompleksitas tugas tidak memiliki pengaruh terhadap kinerja auditor di Inspektorat Provinsi Jawa Tengah. 


\section{Pengaruh motivasi terhadap kinerja auditor.}

Berdasarkan hasil pengujian statistik, hipotesis keempat yaitu motivasi berpengaruh positif terhadap kinerja auditor ditolak karena hasil dari sig/2 menunjukan nilai $0,003<0,05$ dengan koefisien beta negatif sebesar $-0,749$ maka hipotesis penulis ditolak karena berdasarkan hasil pengujian menunjukkan bahwa motivasi berpegaruh negatif terhadap kinerja auditor.

Berdasarkan hasil uji statistik deskriptif variabel motivasi memiliki rata-rata sebesar 29,91 yang dikategorikan tinggi sehingga dapat dikatakan sangat baik. Namun, berdasarkan hasil pengujian menunjukkan bahwa motivasi berpengaruh negatif terhadap kinerja auditor. Hal tersebut mungkin terjadi ketika seorang auditor memiliki motivasi yang tinggi di dalam dirinya untuk memperoleh gaji yang tinggi ataupun kenaikan jabatan namun terdapat keraguan di dalam diri auditor apakah tujuannya dapat tercapai, sehingga akan membuat kinerja dari auditor tersebut menjadi tidak maksimal atau rendah.

\section{Pengaruh ketidakjelasan peran terhadap kinerja auditor.}

Berdasarkan hasil pengujian statistik, hipotesis kelima yaitu ketidakjelasan peran berpengaruh negatif terhadap kinerja auditor ditolak karena hasil dari sig/2 menunjukan nilai $0,124>0,05$ dengan koefisien beta negatif sebesar $-0,352$ maka hipotesis penulis ditolak. Hasil tersebut serupa dengan penelitian Winidiantari dan Widhiyani (2015) yang menyatakan bahwa ketidakjelasan peran tidak berpegaruh terhadap kinerja auditor.

Kondisi tersebut memperlihatkan bahwa pembagian tugas serta informasi dalam melakukan proses audit di Inspektorat Provinsi Jawa Tengah sudah jelas dan tidak terjadi ketimpangan dalam melaksanakan wewenang atau tugas yang diberikan sehingga tidak mengganggu kinerja dari auditor itu sendiri. Hasil penelitian ini juga didukung dengan hasil pengujian statistik deskriptif yang menunjukkan bahwa ketidakjelasan peran ini memiliki rata-rata sebesar 9,94 yang dikategorikan rendah sehingga dapat dikatakan bahwa ketidakjelasan peran tidak berpengaruh terhadap kinerja auditor di Inspektorat Provinsi Jawa Tengah.

\section{SIMPULAN DAN SARAN}

Berdasarkan hasil analisis regresi berganda, maka didapatkan kesimpulan sebagai berikut :

1. Variabel integritas memiliki pengaruh positif terhadap kineja auditor. Hipotesis pertama secara empiris diterima.

2. Variabel kerahasiaan tidak berpengaruh terhadap kinerja auditor. Secara empiris, hipotesis kedua dalam penelitian ini ditolak.

3. Variabel kompleksitas tugas tidak berpengaruh terhadap kinerja auditor. Hipotesis ketiga dalam penelitian ini ditolak.

4. Variabel motivasi berpengaruh negatif terhadap kinerja auditor. Hipotesis keempat dalam penelitian ini ditolak.

5. Variabel ketidakjelasan peran tidak berpengaruh terhadap kinerja auditor. Hipotesis kelima dalam penelitian ini ditolak.

6. Variabel kontrol komitmen organisasional tidak berpengaruh terhadap kinerja auditor.

7. Variabel kontrol kompetensi berpengaruh positif terhadap kinerja auditor. 


\section{Saran}

Berdasarkan penelitian ini didapatkan saran sebagai berikut:

1. Bagi inspektorat agar mempertahankan dan meningkatkan kinerjanya sehingga pelaksanaan pemeriksaan dan pengawasan fungsional dapat lebih baik lagi dimasa yang akan datang.

2. Penelitian selanjutnya dapat mencoba untuk menggunakan objek penelitian yang lain, seperti auditor yang bekerja BPK atau auditor yang bekerja di berbagai kementrian.

3. Penelitian selanjutnya dapat mencoba variabel lain yang dapat mempengaruhi tingkat kinerja auditor di luar dari variabel dalam penelitian ini, seperti pelatihan kerja, pemahaman good governance, kecakapan profesional, dan komitmen pimpinan.

\section{DAFTAR PUSTAKA}

Afriyani, N., dan R. Anugerah. 2014. Pengaruh Kompetensi, Motivasi dan Skeptisme Profesional Terhadap Kualitas Audit Auditor Inspektorat se-Provinsi Riau, JOM Fekon $1(2)$.

Agusniwar, I., dan N. Azis. 2017. Pengaruh Kompleksitas Tugas Dan Locus of Control Terhadap Kinerja Karyawan dan Dampaknya pada Kinerja PT. Bank Rakyat Indonesia Cabang Meulaboh, Jurnal Magister Manajemen Fakultas Ekonomidan Bisnis Unsyiah, $16-24$.

Agustina, L. 2009. Pengaruh Konflik Peran, Ketidakjelasan Peran, dan Kelebihan Peran Terhadap Kepuasan Kerja dan Kinerja Auditor, Jurnal Akuntansi 1 (1), 40-69.

Ananta, A. H. 2013. Pengaruh Independensi Auditor, Komitmen Organisasi, Gaya Kepemimpinan, Budaya Organisasi, Pemahaman Good Governance dan Ketidakjelasan Peran Terhadap Kinerja Auditor. Semarang : Universitas Katolik Soegijapranata.

Andini, G. 2017. Faktor-Faktor yang Mempengaruhi Kinerja Auditor, JOM Fekon 4(1).

Ardianingsih, A. 2013. Hubungan Komite Audit dan Kompleksitas Usaha dengan Audit Fee, Jurnal Ekonomi dan Bisnis 13(2), 20-28.

Ariani, K.G., dan I. Badera. 2015. Pengaruh Integritas, Obyektifitas, Kerahasiaan, Dan Kompetensi Pada Kinerja Auditor Inspektorat Kota Denpasar, E-Jurnal Akuntansi Universitas Udayana 10(1), 182-198.

Arini, T.F. 2010. Pengaruh Persepsi Auditor Internal Atas Kode Etik Terhadap Kinerja Auditor Internal. Surakarta : Universitas Sebelas Maret.

Azhar, A. 2013. Pengaruh Konflik Peran, Ketidakjelasan Peran, Kesan Ketidakpastian Lingkungan, Locus of Control Dan Motivasi Kerja Terhadap Kinerja Auditor (Studi Empiris Pada Kantor Akuntan Publik Di Pekanbaru, Padang Dan Batam), Jurnal Ekonomi 21(4), 1-15.

Budiasih, T.A. 2008. Pengaruh Batasan Waktu dan Kompleksitas Tugas Terhadap Kinerja Auditor. Semarang: Universitas Katolik Soegijapranata.

Darmawan, A.S., dan M.D. Mukzam. 2011. Pengaruh Motivasi Kerja Dan Kemampuan Kerja Terhadap Kinerja Karyawan, 4-6. 
Engko, C. 2007. Pengaruh Kompleksitas Tugas dan Locus of Control Terhadap Hubungan Antara Gaya Kepemimpinan dan Kepuasan Kerja Auditor, JAAI 11(2), 105-124.

Erina, C., dan B. Zein. 2012. Pengaruh Integritas, Objektivitas, Kerahasiaan dan Kompetensi Terhadap Kinerja Aparat Pengawasan Internal Pemerintah, Jurnal Akuntansi Pascasarjana Universitas Syiah Kuala 2(1), 15-27.

Fadjar, A., dan H.F. Firdaus. 2009. Pertimbangan Auditor dalam Mengumpulkan Bukti Audit Terhadap Pendapat Wajar Tapsa Pengecualian. Jurnal Bisnis dan Ekonomi 41(1), 31.

Firdausy, Z., dan M.R. Nazar. 2013. Pengaruh Komitmen Organisasi, Profesionalisme, Konflik Peran, Serta Ketidakjelasan Peran Pada Kinerja Auditor Internal. Bandung: Universitas Telkom, 1-9.

Hartono, J. 2013. Metodologi Penelitian Bisnis. Yogyakarta : BPFE.

Herdhiana, R. 2007. Aspek Hukum Pemeriksaan Koperasi, Educare 4(2), 189-191.

Herlina, L. 2014. Pengaruh Integritas dan Kompetensi Auditor Terhadap Kualitas Audit. Bandung : Universitas Komputer Indonesia, 1-15.

Ilmiyati, F., dan Y. Suhardjo. 2012. Pengaruh Akuntabilitas dan Kompetensi Auditor Terhadap Kualitas Audit. Juraksi 1(1), 43-56.

Irwan, A. 2016. Pengaruh Kompetensi Terhadap Kinerja Pegawai pada Dinas Pendidikan, Kebudayaan, Pemuda dan Olahraga Kabupaten Mamuju Utara. E-Jurnal Katalogis 4(2), 196-208.

Iswara, D., dan A. Rasyidi. 2015. Penerapan Audit Operasional dalam Menilai Efisiensi dan Efektivitas Fungsi Penjualan pada CV. Anugerah Jaya Sidoarjo, Jurnal Akuntansi UBHARA.

Jamilah, S., dan G. Chandrarin. 2007. Pengaruh Gender, Tekanan Ketaatan, dan Kompleksitas Tugas Terhadap Audit Judgment, Simposium Nasional Akuntansi X, 1-30.

Kementerian Pendayagunaan Aparatur Negara RI, P. M. P. A. N. N. P. P. tentang S. A. A. P. I. P. 2008. Menteri Negara Pendayagunaan Aparatur Negara.

Khikmah, S. N., dan E. Priyanto. 2013. Komitmen Organisasi, Locus of Control, dan Kompleksitas Tugas Terhadap Kinerja Audit Internal.

Lusy, dan B. Suryono. 2014. Risk-Based Audit atas Penjualan PT "X”, Jurnal Ilmu dan Riset Akuntansi 3(4).

Manik, N. B., dan S. Sitohang. 2017. Pertumbuhan Perusahaan, Struktur Aktiva, dan Pertumbuhan Penjualan serta Pengaruhnya Terhadap Struktur Modal, Jurnal Ilmu dan Riset Manajemen 6(4).

Murniati, M.P. 2013. Alat-alat Pengujian Hipotesis. Semarang : Universitas Katolik Soegijapranata.

Ngo, S.V.S. 2013. Pengaruh Konflik Peran, Ketidakjelasan Peran, Kelebihan Peran dan Independensi Auditor Terhadap Kinerja Auditor. Semarang: Universitas Katolik Soegijapranata.

Nugroho, A.E., dan N. Brasit. 2011. Pengaruh Coaching Terhadap Motivasi Kerja dan Kinerja Individual. Makassar :Universitas Hasanuddin.

Parhan, I. 2018. Pengaruh Skeptisme Audit, Independensi dan Kompleksitas Tugas Terhadap Audit Judgment, 1-16. 
Revita, M. 2015. Pengaruh Kompetensi, Disiplin Kerja dan Lingkungan Kerja Terhadap Kinerja Pegawai pada Dinas Energi dan Sumber Daya Mineral Kabupaten Sigi, E-Jurnal Katalogis 3(9), 159-170.

Rosalina, A.D. 2014. Pengaruh Kompetensi dan Independensi Auditor Terhadap Kualitas Audit. Bandung : Universitas Widyatama.

Ruchmawati, dan M.Y.B. Kalalo. 2016. Analisis Perencanaan Audit Laporan Keuangan Berdasarkan Standar Profesional Akuntan Publik, Jurnal Berkala Ilmiah Efisiensi 16(3), 670-679.

Rustiarini, N.W. 2013. Pengaruh Kompleksitas Tugas, Tekanan Waktu, dan Sifat Kepribadian pada Kinerja, Makara Seri Sosial Humaniora 17(2), 126-138.

Safitri, D. 2015. Pengaruh Ambiguitas Peran dan Motivasi Terhadap Kinerja Auditor (Studi Empiris Pada Kantor Akuntan Publik di Pekanbaru, Batam, dan Medan), Jurnal Akuntansi 3(2), 160-173.

Sari, N.P.E.R., dan I.K. Suryanawa. 2016. Konflik Peran, Ketidakjelasan Peran, dan Kelebihan Peran Terhadap Kinerja Auditor dengan Tekanan Waktu Sebagai Pemoderasi, E-Jurnal Akuntansi Universitas Udayana 15(2), 1392-1421.

Siregar, E.M. 2012. Pengaruh Kualitas Sumber Daya Manusia, Komitmen Organisasi, dan Motivasi Kerja Dengan Tindakan Supervisi Sebagai Variabel Moderating Terhadap Kinerja Auditor Pada Inspektorat Provinsi Sumatera Utara. Medan: Universitas Sumatera Utara.

Sukriah, I., dan B.A. Inapty. 2009. Pengaruh Pengalaman Kerja, Independensi, Obyektifitas, Integritas dan Kompetensi Terhadap Kualitas Hasil Pemeriksaan, 1-38.

Sulistyawati, A.I., dan D. Triyani. 2012. Pengaruh Komitmen Organisasional dan Profesional Terhadap Kepuasan Kerja Auditor: Motivasi Sebagai Variabel Moderating. Semarang : Universitas Semarang, 459-472.

Surtikanti, dan I. Sunarya. 2012. Pengaruh Kompleksitas Tugas dan Skeptisme Profesional Terhadap Audit Judgment. Bandung : Universitas Komputer Indonesia (4), 1-24.

Susanti, M. 2017. Pengaruh Konflik Peran, Ketidakjelasan Peran, dan Sensitivitas Etika Profesi Terhadap Kinerja Auditor dengan Kecerdasan Emosional sebagai Variabel Moderating, JOM Fekon 4(1).

Temaja, I.P.E.A.W., dan I.M.K. Utama. 2016. Pengaruh Profesionalisme, Kepribadian Hardiness, Motivasi dan Budaya Organisasi pada Kinerja Auditor di Kantor Akuntan Publik, E-Jurnal Akuntansi Universitas Udayana 15(3), 1711-1739.

Triarini, D.A.W., dan N.M.Y. Latrini. 2016. Pengaruh Kompetensi, Skeptisme Profesional, Motivasi, dan Disiplin Terhadap Kualitas Audit Kantor Inspektorat Kabupaten/Kota Bali, E-Jurnal Akuntansi Universitas Udayana 14(2), 1092-1119.

Trisnaningsih, S. 2007. Independensi Auditor dan Komitmen Organisasi sebagai Mediasi Pengaruh Pemahaman Good Governance, Gaya Kepemimpinan dan Budaya Organisasi terhadap Kinerja Auditor, Simposium Nasional Akuntansi X, 1-56.

Trisnaningsih, S. 2011. Faktor-Faktor yang Mempengaruhi Kinerja Dosen Akuntansi, Jurnal Akutansi dan Auditing 8(1), 1-94. 
Triyanthi, M., dan K. Budiartha. 2015. Pengaruh Profesionalisme, Etika Profesi, Independensi, dan Motivasi Kerja pada Kinerja Internal Auditor, E-Jurnal Akuntansi Universitas Udayana 10(3), 797-809.

Valentina, R., dan D.E. Kusumaningrum. 2017. Hubungan Kompetensi dan Motivasi Kerja dengan Kinerja Tenaga Administrasi Sekolah, Jurnal Aministrasi dan Manajemen Pendidikan 1(1), 79-86.

Wati, E., dan N. Aprilla. 2010. Pengaruh Independensi, Gaya Kepemimpinan, Komitmen Organisasi, dan Pemahaman Good Governance Terhadap Kinerja Auditor Pemerintah, Simposium Nasional Akuntansi XII.

Wibowo, R. 2012. Pengaruh Modal, Tenaga Kerja, Bahan Baku, Mesin Terhadap Produksi Industri Kecil Konveksi Desa Padurenan Kecamata Gebog Kabupaten Kudus, Economics Development Analysis Journal 1(2).

Widiyanti, N.N., dan N.L.S. Widhiyani. 2013. Pengaruh Time Pressure, Risiko Audit, Materialitas, dan Prosedur Reviu terhadap Konsistensi Prosedur Audit pada Badan Pemeriksa Keuangan Provinsi Bali, Jurnal Ilmiah Akuntansi dan Bisnis 8(1), 29-35.

Widyaningrum, V. 2013. Pengaruh Independensi Auditor, Komitmen Organisasi, Gaya Kepemimpinan, Budaya Organisasi dan Motivasi Terhadap Kinerja Auditor. Semarang: Universitas Katolik Soegijapranata.

Wildan. 2016. Pengaruh Komitmen Organisasi, Motivasi Kerja dan Disiplin Kerja Terhadap Kinerja Karyawan STIE Pasaman, E-Jurnal Apresiasi Ekonomi 4(3), 191-204.

Winidiantari, P.N., dan N.L.S. Widhiyani. 2015. Pengaruh Konflik Peran, Ketidakjelasan Peran, Struktur Audit, Motivasi dan Kepuasan Kerja pada Kinerja Auditor, E-Jurnal Akuntansi Universitas Udayana 12(1), 249-264.

Yendrawati, R., dan N.R. Narastuti. 2014. Pengaruh Integritas, Obyektivitas, Kerahasiaan, dan Kompetensi Terhadap Kinerja Auditor Pemerintah, Jurnal Akuntansi dan Investasi $15(1)$.

Yusuf, A.E. 2014. Dampak Motivasi Terhadap Peningkatan Kinerja Individu, Humanora $5(1), 494-500$. 